\title{
Epidemiological aspects and treatment of parasitic lesions similar to Stephanofilariasis disease in nursing cows
}

\author{
Aspectos epidemiológicos e tratamento de lesões parasitárias \\ semelhantes à Estefanofilariose em vacas lactantes
}

\author{
Luiz Antônio Franco Silva ${ }^{1 *}$; Rogério Elias Rabelo ${ }^{2}$; Maria Ivete de Moura ${ }^{3}$; \\ Maria Clorinda Soares Fioravanti ${ }^{4}$; Lígia Miranda Ferreira Borges ${ }^{5}$; \\ Caroline Rocha de Oliveira Lima ${ }^{6}$
}

\begin{abstract}
The aim was to describe epidemiological, clinical and histological aspects of parasitic lesions caused by Stephanofilariasis on the udder of nursing cows and to evaluate the viability of a therapeutic protocol. Forty lactating cows with characteristic Stephanofilariasis lesions were divided into two groups, GI and GII. The wounds on the udder of the GI cows were cleansed with sodium hydrochloride and treated topically with an ointment consisting of trichlorphone, ivermectine, dexamethasone, calendula, zinc oxide and an adherent ointment of sodium vaseline, associated with the parenteral application of $1 \%$ ivermectine. GII served as control group and was left untreated. Twelve cows (60\%) of GI had recovered on the $45^{\text {th }}$ day of treatment and 8 cows (40\%) showed clinical cure within 45-60 days. The diagnosis of Stephanofilaria stilesi infection is generally presumptive. Epidemiologically-related aspects, clinical findings and positive response to treatment help to confirm the disease. Histopathological exams also assist in the diagnosis when the presence of nematodes can be revealed, although this finding is not frequent. The therapeutic protocol employed proved to be economically viable and efficient, with recovery of all the lesions.
\end{abstract}

Key words: Bovine, filarid, lesion, therapy, udder

\section{Resumo}

O presente trabalho objetivou descrever aspectos epidemiológicos, clínicos e histológicos das lesões e avaliar a viabilidade de um protocolo terapêutico para estefanofilariose localizada na pele do úbere de vacas lactantes. Utilizou-se no estudo 40 fêmeas bovinas de aptidão para leite em lactação com lesões características de estefanofilariose. Os animais foram distribuídos em dois grupos (GI e GII), sendo as feridas dos bovinos que constituíram o GI higienizadas com hipoclorito de sódio e tratadas diariamente com aplicação tópica de pomada contendo triclorfon, ivermectina, dexametasona, calêndula, óxido de zinco e pomada aderente de vaselina sódica, associada à aplicação parenteral de ivermectina a $1 \%$. O GII foi utilizado como controle não sendo tratado. Do total de bovinos que fizeram parte do GI,

\footnotetext{
1 Assistant Teacher II of surgery clinical animal. Sector of Veterinary School, Goiânia. UFG, Brazil. E-mail: lafranco@vet.ufg.br

${ }^{2}$ Teacher of surgery clinical animal. Sector of Veterinary School, Jataí Campus. UFG. Brazil. E-mail: rabelovet@yahoo.com.br

${ }^{3}$ Degree of doctor in animal science. Post-graduate of the School of Veterinary. UFG. Brazil. E-mail: medivetemoura@yahoo.com. br

${ }^{4}$ Assistant Teacher II of medical clinical animal. Sector of Veterinary School. Goiânia. UFG. Brazil. E-mail:clorinda@vet.ufg.br

${ }^{5}$ Assistant Teacher of Parasitology of the discipline. Institute of Tropical Diseases and Public Health. UFG, Brazil. E-mail: ligia@ iptsp.ufg.br

${ }^{6}$ Degree of doctor in animal science. Post-graduate of the School of Veterinary. UFG. Brazil. E-mail: carolrochavet@hotmail. com

* Autor para correspondência
} 
$12(60 \%)$ recuperaram-se até o $45^{\circ}$ dia de tratamento e oito (40\%) tiveram a cura clínica entre 45-60 dias. O diagnóstico de estefanofilariose geralmente é presuntivo, sendo que os aspectos relacionados à epidemiologia, achados clínicos e à resposta positiva ao tratamento auxiliam na confirmação da enfermidade. Os exames histopatológicos auxiliam no diagnóstico revelando a presença do nematódeo, embora a observação do parasito não seja freqüente. O protocolo terapêutico empregado mostrou-se economicamente viável e eficiente, com recuperação de todas as lesões.

Palavras-chave: Bovino, fillarídeo, lesão, terapêutica, úbere

\section{Introduction}

Stephanofilariasis a parasitic disease caused by worms of the genus Stephanofilaria which causes skin lesions characterized by alopecia and ulcerative nodular dermatitis in bovines, buffaloes and goats, among other mammals. In many situations, due to the obstruction of the lymph ducts, the wound may reappear. While recent studies characterize it as a zoonosis, its occurrence in humans is considered rare (NOVAES et al., 2006). Five species of the genus Stephanofilaria have been described as bovine parasites in a number of regions of the world; their intermediate hosts include Haematobia irritans, Musca conducens, Musca planiceps and Musca autumnalis (RIVIERA; AYCARDI, 1985).

Stephanofilaria can be characterized as the agent of a disease commonly observed in exuberant high-occupancy pastures with large quantities of wet feces, principally in the hot and rainy seasons (SUTHERST et al., 2006). These factors result in a greater proliferation of vectors. In this situation, the flies are attracted by exudate originating from open cutaneous lesions infested with adult worm parasites, with the consequent ingestion of microfilariae (URQUHART et al., 1998). The final host is infected when the flies deposit larvae in the not injured skin, causing inflammation and destruction of the hair follicles and epithelian cells (URQUHART et al., 1998; NOVAES; MIYASHIDA, 2006). Stephanofilaria occupies the hair follicle and the dermic papilla through blood circulation, with the consequent formation of areas of alopecia, papules and intense itching, giving rise to lesions which may reach a diameter of $25 \mathrm{~cm}$ (SMITH; JONES, 1962).
The lesions may be present in different parts of the body, particularly the scrotum (WATRELOTVIRIEUX; PIN, 2006), pelvic members (NOVAES et al., 2006), neck (SUTHERST et al., 2006), and udder (SILVA; BRAGA; FIORAVANTI, 2001). The disease is recognized as one of the main causes of udder skin lesions in cows. In most cases, the diagnosis is based on clinical signs, patient behavior and success of the adopted therapy. This is related to difficulty in isolating and identifying microfilariae, given the limited quantity of this parasite at the site of the lesion (NOORUDDIN; HOQUE, 1985; URQUHART et al., 1998). It may be added that because the discomfort and intense pain from the lesion result in stress and low food consumption, the negative impact on the production of milk and meat is considerable (NOORUDDIN; HOQUE, 1985; NOVAES et al., 1988; SILVA; BRAGA; FIORAVANTI, 2001). Treatment of Stephanofilariasis lesions is laborious and may be time-consuming, making the continuation of the animal in the herd economically unviable (NOVAES; MIYASHIDA, 2006).

National or even regional epidemological information has not been found. Some authors, however, reported a greater frequency of this parasite in Bos taurus breeds and older animals in a study of herds in northern Australia (SUTHERST et al., 2006). The same authors also report that the size of the lesion was proportional to the size and age of the animal and that females presented largerdiameter lesions than did the males. In endemic areas, the incidence of this infection can reach $90 \%$. Its occurrence is in large part related to the type of grass on the property (URQUHART et al., 1998). 
Treatments for stephanofilariasis is based in antihelminthics like ivermectine, levamisol, amitraz and himax, with satisfactory results (GILL et al., 1988; BANDYOPADHYAY, 1994; RAI et al., 1994; PRAMANIK et al., 1995). Organophosphate compounds for topical use such as trichlorphon may be effective since the drug acts on the nemotodes, causing spastic paralysis and the consequent death of the parasite (URQUHART et al., 1998). Other authors have suggested an ointment based on the oils and extracts of natural repellant plants for the treatment of the disease in association with topical deltametrine, in addition to perenteral applications of ivermectine or levamisol (SASMAL; PAHARI, 1995). The researchers, however, did not report the costs of these protocols.

The purpose of the present report was to evaluate the effectiveness of a therapeutic protocol, and the economic, epidemiological, clinical and histological aspects of udder lesions characteristic of Stephanofilaria sp infection in dairy cows.

\section{Material and Methods}

The study was carried out from 1997 to 2007 in the universe of 3,762 nursing cows from 28 dairy farms in the state of Goiás, Brazil. Forty cows with udder lesions having the clinical characteristics of Stephanofilariasis disease (JOHNSON et al., 1981; URQUHART et al., 1998; SILVA; BRAGA; FIORAVANTI, 2001) were assigned at random to one of two groups, GI or GII.

To confirm the clinical suspicion, tissue fragments approximately $2 \mathrm{~cm}$ long, $0.5 \mathrm{~cm}$ wide and $0.5 \mathrm{~cm}$ thick were taken. These included the edge of the healthy portion of skin as well as the diseased area in order to carry out a histopathological exam. For this purpose, the area was disinfected and local anesthetic block was effected using $2 \%$ lidocaine hidrochloride (Dorfin ${ }^{\circledR}$, Hertape Ltda, Juatuba/ $\mathrm{MG})$. After removal of the specimens, the skin in the incised area was sutured in a simple separated pattern with a 2.0 nylon thread. The fragments were fixed in $10 \%$ buffered formaldehyde, included in paraffin, cut with a revolving-type microtome and stained with hematoxiline-eosine (HE) and Mallory's phosphotungstic acid (PROPHET et al. 1992) and Congo red and modified toluidine blue to visualize the inflammatory cells (CONCEIÇÃO, 2003). The Grocott-Gomon silver impregnation technique was used to detect the presence of fungi (FARIA et al., 2005); Gram was used to visualize bacterial flora; and modified periodic acid-Schiff (PAS) was used to detect polysaccharides and fungi (LUNA, 1968; TARPLEY; MESCHTER; TYLER, 1984).

In parallel, tissue samples of similar dimensions were taken at random from six (15\%) cows and were subjected to the modified Baermann method. These samples were rolled in gauze and placed in a $0.9 \%$ saline solution. After a period of 24 hours, this tube was removed and centrifuged at $200 \mathrm{~g}$ for 5 minutes. The supernatant was immediately discarded and the sediment resuspended in $5 \mathrm{ml}$ of saline solution. Later, the contents were homogenized and three aliquots of $10 \mu 1$ were removed from the tube and deposited on a glass slide which was placed under a stereoscopic microscope $(25 \mathrm{x})$ in an attempt to find the parasite as well as to analyze its morphological forms and characteristics.

The epidemiological evaluation of the disease was carried out by means of a closed-end structured questionnaire, developed on the basis of another author's report (THRUSFIELD, 2004) and administered on all the farms and filled out by the owner, technical contact, or manager.

The GI cow's wounds were cleaned with sodium hypochlorite and treated topically on a daily basis until the scarring with an ointment consisting of trichlorphon (20g), ivermectine (50mg), dexamethasone $(0.5 \mathrm{mg})$, calendula $(25 \mathrm{~g})$, zinc oxide $(50 \mathrm{~g})$ and sodium vaseline adherent ointment (450g) (Compounded ointment. Farmogral Farmácia de Manipulação Ltda, Brasília/DF). In addition, 0.2 $\mathrm{mg} / \mathrm{kg}$ of body weight of ivermectine (Ranger $1 \%$ 
Ivermectine solution ValléS/AProdutos Veterinários. Montes Claros/MG) was given subcutaneously on the first and 28th days of treatment. The wounds of the animals in group GII were only cleaned with distilled water.

Every two weeks, the wounds were evaluated for scarring, irrespective of the group. The treatment was considered successful when the complete scarring of the wound was verified, with an absence of crusts and reappearance of hair in the affected area. The evaluation period was 90 days.

Costs of the procedure were estimated for the GI bovines, taking into account only material consumed during the treatment, such as syringes, needles, ivermectine and the compounded ointment. Although the treatment with ivermectin is required disposing of milk it was not evaluated the cost, because it was intended for alimentation of feeding calves. A stress-related decrease in the animals' production, a drop in milk production and milk disposal resulting from the use of the medicines were estimated on the basis of owner-supplied information only.

Descriptive statistics (SAMPAIO, 1998) were used to evaluate epidemological, histopathological, and clinical data related to the treated (GI) and nontreated (GII) animals.

\section{Results and Discussion}

Of the 40 animals in the study, 23 (57.5\%) were treated during the period between Octoberand March, a season in the region under study distinguished by its high temperatures and precipitation. In Goiás, Brazil, the spring and summer are traditionally hightemperature seasons, with an average temperature of $23.7^{\circ} \mathrm{C}$ and high rainfall, with an average of $210.5 \mathrm{~mm}$ (PADUA et al., 2003). While none of the farms used artificial irrigation, which according to other researchers may result in an increase in Stephanofilaria stilesi diasease (URQUHART et al., 1998), it is believed that the high temperatures and precipitation contributed to an increase in the disease. These were therefore considered to be extremely relevant epidemiological factors, given the greater infestation of muscidae on these farms and the role of these vectors in the biological cycle of parasitosis during the period of the study.

This observation coincides with the statements of other authors (RIVIERA; AYCARDI, 1985; NOVAES etal., 1988; IIDA; TAIRA, 1994; NOVAES et al., 2006), who have related climatic conditions similar to those in this study to a substantial number of vectors such as horn fly (Haematobia irritans) and tabanidae, which not only attack the cattle, but may also carry microfilariae from one individual to another, thus perpetuating the cycle. Some authors (VALÉRIO; GUIMARÃES, 1983) blame the horn fly for the transmission of a variety of illnesses, including Stephanofilaria stilesi disease. There are references to muscidae vectors in human and animal stephanofilariasis cases, with the same vectors responsible for the transmission of other diseases such as elephantiasis and onchocerciasis (NOVAES; MIYASHIDA, 2006, 2007).

In addition to climatic conditions favorable to the proliferation of muscidae, biosecurity criteria related to the treatment and storage of excrement were considered unsatisfactory on the 28 farms visited. An excess of organic material and soft, moist feces in animal handling areas such as the milking room and waiting corral as well as manure pits built in unsuitable locations and operated improperly contribute to the greater incidence of flies. This corroborates the findings of other authors (URQUHART et al., 1998; NOVAES; MIYASHIDA, 2006, 2007). Biosecurity measures have been identified as fundamental mechanisms in the prevention of various infectious/contagious and parasitic diseases (SOBESTIANSKY, 2002).

The age of the cows varied between 28 and 96 months and average daily production was 20.6 liters. In $34(85 \%)$ of the 40 cows studied, the wounds were located in the border region between 
the ventral abdominal wall and the cranial udder insertion (Figure 1A) and in $6(15 \%)$ it was located in the ventral portion of the udder, at the midway point between the teats (Figure 1B). In $33(82.5 \%)$ cows, the udder was developed, in lesions projecting cranially and forming a moist sac between the gland and the ventral abdominal wall. On the basis of this information and owners' reports, it was possible to infer that this diverticulum made possible the accumulation of dirt, which, associated with the presence of ectoparasites like ticks, culminated in skin injuries which favored the development of the disease.

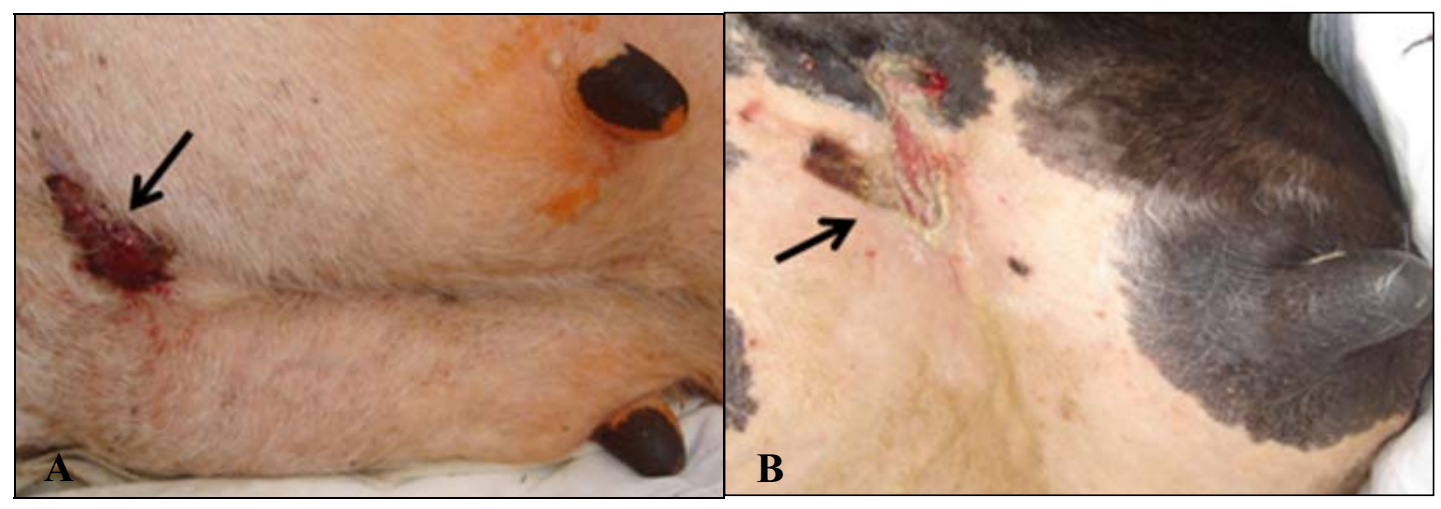

Figure 1. Macroscopic and microscopic aspects of the Sthephofilariosis. (A) Clinical presentation of lesion characteristic of Stephanophilaria stilesi on the udder of a lactating cow; (B) Located in the border region between the ventral abdominal wall and the cranial udder insertion, and between the teats.

A similar situation was reported by researchers, who described the cranial udder region as predisposed to this parasitosis (SILVA; ; BRAGA; FIORAVANTI, 2001). Other authors, however, point to the head, neck, dewlap, sternum, thorax, tail, and the digits as the regions with the greatest occurrence of this type of lesion (JOHNSON et al., 1981, CHATTERJEE; CHAKRABARTI, 1983). While it is not possible to explain this discrepancy, it is believed that factors such as lactational period, environment, and climate, and particularly those related to the region where the experiment was carried out, such as high temperatures and humidity with the consequent increase in the fly population in the facilities, may explain in part the greater frequency of lesions in the udder cranial region.

In all animals examined the lesions were moist and exudative, with crusts and a diameter of between three and ten centimeters (Figure 1B). Several authors found no relation between lesion size and animal size or age (SUTHERST et al.,
2006). Others described the same characteristics noted in wounds described for Stephanofilariosis stilesi disease (JOHSON et al., 1981; URQUHART et al., 1998). These lesions may reach a diameter of $25 \mathrm{~cm}$, causing the animal considerable discomfort, which was also observed in this study.

It may be added that when the questionnaire was applied, it was found that five (12.5\%) cows with lesions characteristic of Stephanofilariasis sp disease were being treated with antibiotics as a result of clinical mastitis. Despite the lack of support in the literature for a relation between parasitic lesions and episodes of mastitis, it is believed that this type of injury and the disease may be intimately linked, particularly when taking into account the secondary bacterial contamination of the injury and the ease of contact with the teat ostium, especially during milking, whether provided by the milking machine or muscidae vectors. Other researchers have also referred to the importance of muscidae vectors in the incidence of mastitis, and consequently in 
milk quality, but they have not related the problem to udder lesions (FONSECA; SANTOS, 2000). However, others have associated mastitis with the presence of udder abscesses (SILVA; BRAGA; FIORAVANTI, 2001).

The information concurning the lesion pattern, its clinical propression, including their apparent disappearance in the winter and negative response to treatments employing conventional auxiliary healing and repellant products, led to the presumptive diagnosis of Stephanofilariasis sp disease. Backing up this suspicion, other authors have reported that the lesions this disease tend to be less frequent in the herd during winter (URQUHART et al., 1998). This seasonality is related to the unfavorable environment for the development of either the vectors or microfilarids.

The collection of tissue specimens in the border area between the lesion and healthy tissue for the histological examination resulted in moderate hemorrhage in stephanofilariasis lesions of 12 cows (30\%). This complication was considered a limiting factor, since it resulted in the collection of smaller fragments of the affected tissue. It is believed that this fact negatively affected the locating and identification of the microfilarídeo, since evaluation of the histological cuts revealed the nematode in only one $(2.5 \%)$ sample. This finding is in keeping with those of other researchers, who claimed that it was difficult to view the nematode in histological cuts (URQUHART et al., 1998). However, the authors did not relate the size of the tissue fragments obtained by means of biopsy to viewing of the parasite and did not report difficulties or complications during collection such as those experienced in this study.

The main histological abnormalities noted were liquifaction necrosis associated with inflammatory polymorphonuclear and eosinophilic infiltrate, with multifocal hemorrhage areas. When viewed, the parasite appeared flattened, with an irregular and undulating surface, numerous well-defined fixing points in its cuticle and reproductive and digestive tracts (Figure 2). These histological characteristics were similar to those reported by other researchers, who observed the worms surrounded by an inflammation zone containing eosinophiles, lymphocytes, neutrophils, histiocytes, and frequently, a layer of conjunctive tissue (JONES; HUNT; KING, 2000). For these authors, the presence of eosinophiles in smears obtained from lesions containing Stephanofilariasis $\mathrm{sp}$ is considered a histological characteristic pattern.

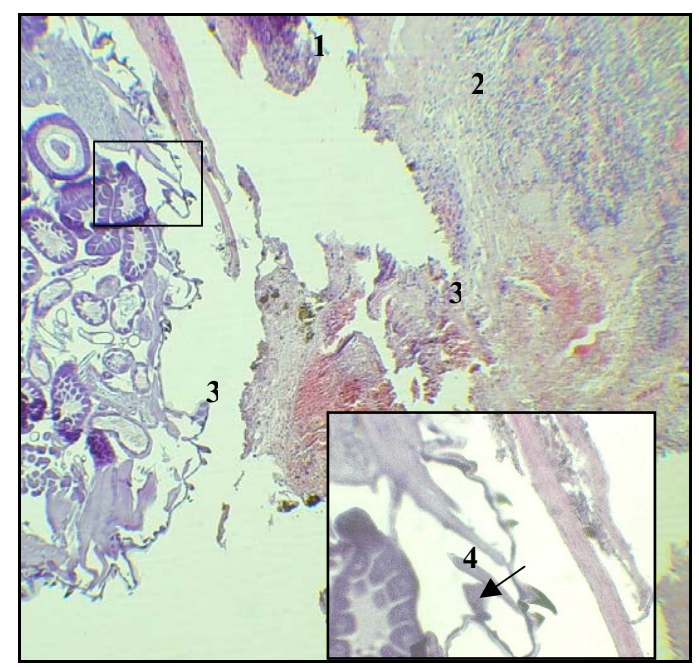

Figure 2. Photomicrograph of bovine mammary gland skin showing the presence of a flattened parasite with an irregular, undulating surface. The histological alterations which appeared: (1) Liquefaction necrosis. (2) Polymorphonuclear and eosinophilic inflammatory infiltrate. (3) Multifocal hemorrhage areas. HE, Obj.3.5x. (4) Inset: fixing points in the cuticle of the parasite (arrow). HE, Obj.40x. 
Another alteration that stood out in the histological samples was the presence of hyperceratosis and parakeratosis in the epidermis, in addition to severe dermatitis, findings which were also taken by researchers as indicative of the disease (JONES; HUNT; KING, 2000). Probably, these findings are related to the death of the parasite and the consequent sensitization of the host.

Even using the modified Baerman method (BARÇANTE et al., 2003) for viewing and identifying the nematode Stephanofilariasis stilesi, it was not possible to observe any of these parasites in the six tissue samples. This may be related to the small volume of fragment collected in the biopsies, as well as the limited number of parasites in the wound, as pointed out by other authors (URQUHART et al., 1998). Other researchers have described the successful viewing and identification of the larval forms of Stephanofilaria sp in humans using direct microscopy with 400x magnification on both the epidermal surface and in blood circulation (NOVAES; MIYASHIDA, 2006, 2007).

Miyakawa, Reis and Lisboa (2008) reported an essay in which direct visualization enabled the identification of the parasite in $100 \%$ of the samples, when histological examination had not demonstrated parasites, misdiagnosing the animals as negative. The direct observation technique consists of inducing parasite migration from the tissue to the saline solution, in an easy, simple, effective and affordable method.

Viewing of fungi was not possible, although in some samples untyped bacterial forms such as cocobacilli and spirochetes were present. While it was not possible to relate microfilaria as a primary factor in the wounds under discussion, it is believed that the bacterial forms present there would be secondarily related to the lesions.

Disinfecting the lesions with distilled water facilitated the removal of crusts and dirt, making possible greater contact between the wounds and the ointment which was applied later. The formulation proposed for local treatment in to GI demonstrated good tissue adherence, with remnants of the ointment in the wounds for up to 24 hours after application. This advantage may be attributed to the zinc oxide and vaseline, which provided longer contact of trichlorphon and ivermectine with the lesion. However, the greater length of the time that the product remained in contact with the wound may have facilitated its action on the microfilaria, in addition to efficiently promoting the control and prevention of myiasis. While not specifically referring to Stephanofilariasis, a number of researchers have highlighted the importance for drugs compounded in ointments to be well fixed and long-lasting at the lesion site (OLIVEIRA et al., 2000; AMARAL et al., 2004).

Parenteral ivermectine may also have contributed to the success of the treatment, since, in theory, it promoted the maintenance of satisfactory levels of the drug in the wound by supplying more of it for when licking by the animal removed some of the ointment. Ivermectine is an excellent filaricide and is widely used in the treatment and prevention of cutaneous myiases (SILVA; BRAGA; FIORAVANTI, 2001; AMARAL et al., 2004). Researchers recommend this drug in the topical or parenteral treatment of animals with lesions caused by nematodes with good recovery rates (SASMAL; PAHARI, 1995, SILVA; BRAGA; FIORAVANTI, 2001).

While reports of the parasiticide action of calendula have not been found in the literature, properties of the active principle, such as the stimulation of cell division (LAVAGNA et al. 2001), may have contributed to the success of the treatment.

Twelve (60\%) GI cows had recovered by the 45 th day of treatment, and eight (40\%) were clinically cured in 45-60 days. Animals presenting lesions with a healing score three and the consequent total disappearance of the wounds, absence of crust and the reappearance of hair in the affected region were 
considered cured. Some researchers have limited themselves to describing the treatment used, without specifying recovery time (SASMAL; PAHARI, 1995; URQUHART et al., 1998). Only three (15\%) of the animals in GII showed an improvement in the appearance of the wounds, possibly due to the disinfection which removed crusts and dirt from the lesions, but the cows were not cured during the 90-day evaluation period. Therefore, comparing the two therapeutic protocols and based on information from other researchers that the diagnosis of Stephanofilariasis disease is generally clinical and therapeutic (URQUHART et al., 1998, NOORUDDIN; HOQUE, 1985), it can be argued that the recovery of the GI animals reinforces the clinical suspicion of this disease.

According to owners reports, cows with these stein udder lesions generally produce less milk, probably due to the discomfort caused by the constant presence of flies around the wounds, which is manifestedly translate into frequent abdominal kicking. They estimate that, after the animals' recovery, milk production increased by approximately $10 \%$. Although subjectively analyzed, this information reinforces the economic importance of the disease. Some authors relate a drop in leather quality to economic losses due to Stephanofilariosis $s p$ (NOORUDDIN; HOQUE, 1985, URQUHART et al., 1998). An intense painful reaction in the areas of the lesions and stress to the animals due to the presence of flies result in significant losses when compared to other bovine skin damage. While these authors did not quantify these losses in monetary terms, in the present study it was clear that, when the problem occurs on a farm, these amounts may increase production costs to such an extent that the adoption of a therapeutic protocol such as the one described here is unviable.

The estimated current cost per animal of the therapeutic protocol adopted in this study was
R\$ 127.64 or U\$ 55.26. Considering an average lactation period of 250 days and an average daily production of $20 \mathrm{~L}$ for cows with the characteristics of those used in this experiment, a total milk production may be calculated at approximately 5.000L. Information furnished by farm owners concerning Stephanofilariasis related losses would indicate that at the end of lactation, the affected animal may have produced 500L less milk. If the commercial price of milk is R $\$ 0.40$ (US\$ 0.19) per liter, losses would be R $\$ 200.00$ (US\$ 98.03). Thus, the cost of the therapeutic protocol adopted for this disease is justified. It was not computed in the total cost the value of discharged milk because it was intended for alimentation of feeding calves. If the disposal of milk was considered, from previous calculations based on an output of $20 \mathrm{~L} /$ cow/day, within 28 days of treatment, with 20 animals, the treatment would be impracticable.

\section{Conclusions}

It may be concluded that:

The observed wounds are characteristic of parasitic lesions caused by filarid nematodes in cattle.

The diagnosis of stephanophilariasis diseases in nursing cows is generally presumptive, since epidemiologically-related aspects, clinical findings and a positive response to the treatment may help to confirm the disease.

A definite diagnosis may be obtained through histopathological exams revealing the presence of nematodes in tissue samples collected from the lesion, although observation of the parasite is not frequent.

The therapeutic protocol employed was shown to be economically viable and efficient, with recovery of all the lesions. 


\section{Referências}

AMARAL, A. V. C.; VIANA, F. A .B.; SILVA, L. A. F.; EURÍDES, D.; MOURA, L. R. C.; MOREIRA, M. Formulário médico veterinário. Goiânia: Kelps Editora, 2004. 152 p.

BANDYOPADHYAY, B. Treatment of stephanofilariasis [Stephanofilaria assamensis in cattle] with Amitraz. The Indian Veterinary Journal, Índia, v. 71, n. 7, p. 716, 1994.

BARÇANTE, J. M. P.; BARÇANTE, T. A.; DIAS, S. R. C.; VIEIRA, L. Q.; LIMA, W. S.; NEGRÃO-CORRÊA, D. A method to obtain Angyostrongilus vasorum firststage larvae from dog faces. Parasitology Research, Germany, v. 89, n. 2, p. 89-93, 2003.

CHATTERJEE, A.; CHAKRABARTI, A. Some uncommon lesions of Stephanofilarial dermatitis on cattle of West Bengal (India). Indian Journal Animal Health, Korkata, v. 22, n. 1, p. 69-70, 1983.

CONCEIÇÃO, M. Aspectos histológicos e morfométricos da pele de cães do nascimento aos 70 dias de idade, clinicamente saudáveis. 2003. Tese (Doutorado) - Faculdade de Medicina Veterinária e Zootecnia. Universidade Estadual Paulista, Botucatu.

FARIA, M. R.; MESSINGER, A. C.; SCARTON, F. B. Histoplasmose nasal e oral em paciente imunocompetente: relato de caso. Caderno de Debates da Revista Brasileira de Otorrinolaringologia, São Paulo, n. 71, ed. 6, p. 37 42, 2005.

FONSECA, L. F. L.; SANTOS, M. V. Qualidade do leite e controle de mastite. São Paulo: Lemos, 2000. 174 p.

GILL, B. S.; BALAKRISHNAN, P.; HOSSAIN, M.; SINGH, J. Treatment of 'humpsore'- stephanofilariasis of cattle-with ivermectin. Indian Journal of Animal Sciences, Warszawa, v. 58, n. 5, p. 552-560, 1988.

IIDA, M.; TAIRA, N. Two cases of parafilariasis in dairy cattle and treatment of hemorrhage with levamisole tropical application. American Journal Veterinary Medicine Science. Chicago, v. 56, n. 1, p. 203-205, 1994.

JOHNSON, S. J.; PARKER, R. J.; NORTON, J. H.; JAQUES, P. A.; GRIMSHAW, A. A. Stephanofilariasis in cattle. Australian Veterinary Journal, Austrália, v. 57, n. 57, p. 411-413. 1981.

JONES, T. C.; HUNT, R. D.; KING N, W. Patologia veterinária. 6. ed. São Paulo: Manole, 2000. 1415 p.

LAVAGNA, S. M.; CHIMENTI, P.; OTTAVIANI, A.; BIZARRI, B. Efficacy of Hypericum and Calendula oils in the epithelial reconstruction of surgical wounds in childbirth with caesarean section. Fármaco, Roma, v. 56, n. 5/7, p. 451-453, 2001.

LUNA, L. G. Manual of histologic staining methods of the armed forces institute of pathology. 3. ed. New York: McGraw-Hill, 1968. 258 p.

MIYAKAWA, V.; REIS, A. C.; LISBOA, J.A. N. Aspectos clínicos e diagnóstico da estefanofilariose em vacas leiteiras. Revista Brasileira de Parasitologia Veterinária, São Paulo, v. 17, p. 172-174, 2008. Suplemento 1.

NOORUDDIN, M.; HOQUE, H. F. Stephanofilariasis in cattle. Agri-Practice, Montréal, v. 6, n. 6, p. 36-39. 1985.

NOVAES, A. P.; BAGNATO, V. S.; MIYASHIDA, A. Y.; FLORES, F. L. E.; KURACHI, C. Estefanofilariose: uma zoonose. São Carlos: Embrapa Instrumentação Agropecuária, 2006. 14 p. (Série Documentos, n. 21).

NOVAES, A. P.; COSTA, A. J. S.; BARBOSA, R. T.; MOREIRA, D. P.; RUZZA, F. J. Dermatite ulcerosa em bovinos provocada por Stephanofilaria. Pesquisa Agropecuária Brasileira, Rio de Janeiro, v. 23, n. 8, p. 927-929. 1988.

NOVAES, A. P.; MIYASHIDA, A. Y. Estefanofilariose, vetores e mecanismo de transmissão: uma nota preliminar. São Carlos: Embrapa Instrumentação Agropecuária, 2006. 11 p. (Série Documentos, n. 22).

Estefanofilariose em humanos: ocorrência e mecanismo de transmissão. Revista Sociedade Brasileira de Medicina Tropical, Rio de Janeiro, v. 40, n. 2, p. 250252, 2007.

OLIVEIRA, S. T.; LEME, M. C.; PIPPI, N. L.; RAISER, A. G.; MANFRON, M. P. Formulações de confrei (Symphytum officinale L.) na cicatrização de feridas cutâneas de ratos. Revista Faculdades de Zootecnia Veterináira e Agronomia. Uruguaiana, v. 7/8, n. 1, p. 6165, 2000.

PADUA, J. T.; OLIVEIRA, M. P.; SILVA, L. A. F.; VIEIRA, L. S.; FIGUERÊDO, E. J.; MORALES, D. C. S. P.; CARRIJO, L. H. D.; MARTINS, A. F. C. Efeitos de métodos de castração e do uso de vermífugos sobre o ganho em peso de bovinos mestiços leiteiros. Revista Ciência Animal Brasileira, Goiânia, v. 4, n. 1, p. 38, 2003.

PRAMANIK, S.; SASMAL, N. K.; BASU, A.; MUKHERJEE, G. S. Therapeutic evaluation of the efficacy of Himax alone and as adjunct to other anthelmintic drugs against stephanofilarial dermatitis in cattle. Indian Journal Animal Sciences, Warszawa, v. 17, n. 2, p. 57-60, 1995. 
PROPHET, E. B.; MILLS, B.; ARRIGTON, J. B.; SOBIN, L. H. Laboratory methods in histotechnology. Washington: Armed Forces Institute of Pathology, 1992. $275 \mathrm{p}$.

RAI, R. B.; AHLAWAT, S. P. S.; SURGRIV, S.; NAGARAJAN, V.; SINGH, S. Levamisole hydrochloride: an effective treatment for stephanofilarial dermatitis (humpsore) in cattle. Tropical Animal Health and Production, Boston, v. 26, n. 3, p. 175-176, 1994.

RIVIERA, B.; AYCARDI, E. R. Epidemiological evaluation of external parasites in cattle from the Brazilian cerrados and the colombian eastern plains. Zentralblatt Fur Veterinarmedizin Reihe. Germany, v. 32, n. 6, p. 417424, 1985.

SAMPAIO, I. B. M. Estatística aplicada à experimentação animal. Belo Horizonte: FEPMVZ, 1998. 221 p.

SASMAL, N. K.; PAHARI, T. K. Comparative efficacy of levamisole, ivermectin and Himax-Butox ointment against 'Humpsore'in cattle. The Indian Journal of Medical Research. Índia, v. 17, n. 1, p. 69-73, 1995.

SILVA, L. A. F.; BRAGA, C. A. S. B.; FIORAVANTI, M. C. S. Estefanofilariose em úbere de vacas lactantes: uma proposta de tratamento. In: CONGRESSO BRASILEIRO MEDICINA VETERINÁRIA, 28., 2001, Salvador. Anais... Salvador: Studio R, 2001. p. 109.

SMITH, H. A.; JONES, T. C. Patologia veterinária. México: Union Tipográfica Editorial Hispano Americana, 1962. $1061 \mathrm{p}$.
SOBESTIANSKY, J. Sistemas intensivos de produção de suínos: programa de biossegurança. 3. ed. Goiânia: Art, 2002. $108 \mathrm{p}$.

SUTHERST, R. W.; BOURNE, A. S.; MAYWALD, G. F.; SEIFERT, G. W. Prevalence, severity, and heritability of Stefanofilaria lesions on cattle in central and sourthern Queensland. Australian Journal Agricultural Research, Australia, v. 57, n. 7, p. 743-750, 2006.

TARPLEY, J. E.; MESCHTER, C. L.; TYLER, D. E. Modified congo-red acidified toluidine blue estrain: anil tecnique for simultaneous staing of eosinophyls and maste cells in paraffin tissue section. Journal Histotechnology, United State, v. 74, n. 6, p. 141-142. 1984.

THRUSFIELD, M. Epidemiologia veterinária. São Paulo: Editora Roca, 2004. 572 p.

URQUHART, G. M.; ARMOUR, J.; DUCAN, J. L.; DUNN, A. M.; JENNINGS, F. W. Parasitologia veterinária. Rio de Janeiro: Guanabara Koogan, 1998. $306 \mathrm{p}$.

VALÉRIO, J. R.; GUIMARÃES, J. H. Sobre a ocorrência de uma nova praga Haematobia irritans L. (Diptera: Muscidae) no Brasil. Revista Brasileira de Zoologia, São Paulo, v. 1, n. 4, p. 417-418, 1983.

WATRELOT-VIRIEUX; PIN, D. Chronic eosinophilic dermatitis in the scrotal area associated with Stephanofilariasis infestation of Charolais bull in France. Journal Veterinary Medicine, Unidet State, v. 53, p. 150152. 2006. Serie B. 